UDK: 82-84:373.3.091.214

Prethodno priopćenje

\title{
POSLOVIGE U NIŽIM RAZREDIMA OSNOVNE ŠKOLE
}

\section{Vesna Grahovac-Pražić}

Odjel za nastavničke studije u Gospiću

Sveučilište u Zadru

Republika Hrvatska

vesnagp@net.hr

\section{Katarina Vukelić}

Odjel za nastavničke studije u Gospiću Sveučilište u Zadru

Republika Hrvatska

ketyvukelic95@gmail.com 


\section{SAŽETAK}

Novi kurikul iz 2019. godine za niže razrede osnovne škole u Hrvatskoj među preporučene književne tekstove za nastavu uvodi i poslovice. $U$ radu se polazi od teorijskog određenja poslovica i utvrđuje prisustvo istih u učenju ipoučavanju u prošlim vremenima čime se pokazuje opravdanost prisutnosti poslovica u nastavi danas. Analiza udžbenika na izabranom uzorku daje pregled položaja poslovica u nastavi koje se pojavljuju kao popratni metodički materijal uz književne i jezične sadržaje nastave. U radu je provedeno istraživanje komunikacije učenika s poslovicama kao zgusnutom i sažetom formom te se utvrđuje postojanje recepcijskih zapreka.

Ključne riječi: nastava, poslovica, učenik, učitelj, udžbenik. 


\section{UVOD}

Poslovice ${ }^{1}$ kao književnousmeni oblik prisutne su u kulturama diljem svijeta, tako i u hrvatskoj kulturi gdje se poslovice pojavljuju već od srednjeg vijeka u pisanim tekstovima.

Književni kritičari poslovice izdvajaju kao jednostavne i male književne oblike, tj. nazivaju ih književnim mikrostrukturama ili minijaturama (Bagić, 2012; Kekez, 1996). Novije teorije književnosti ih svrstavaju prema strukturi u najjednostavnije i najsitnije oblike, dok ih kroz prošlost znanost nije određivala prema strukturi književnih djela. Poslovica kao minimalistički književni oblik ima bezvremenski način izražavanja koji se smatra bitnim obilježjem jezika te se tako potvrđuje njihova ahistoričnost i agegrafičnost (Visinko, 2018). One svjedoče o zajedničkim vrijednostima života, a upravo to ističe njihovu jedinstvenost u prostoru i vremenu.

Solar (1984) definira poslovice kao izjave ili smjernice u kojima je sažeto iskazana neka specifičnost ili pravilo koje je općenito vezano uz sam život, čovjeka ili prirodu te specifičnosti koje su vezane uz ponašanje čovjeka ili prirode. Kekez definira poslovicu: „Poslovica je samosvojan usmenoknjiževni oblik, sa zasebnim oblikovnim zakonitostima, zasebnom estetikom i izvedbom." $(1996,13)$. Jolles ih stavlja u ovaj kontekst: „Time je pak, po našem shvaćanju, rečeno da postoji jednostavni oblik koji zovemo izrekom i da se taj jednostavni oblik ostvaruje u poslovici.“ $(2000,144)$. Bagić (2012) obrazlaže poslovicu kao pučku izreku koja na zoran način iznosi neku dopadljivu činjenicu koju je društvo prihvatilo te ju kao takvu može upotrijebiti u određenim životnim situacijama. Kontekst poslovice ovisi o zajednici u kojoj je nastala, tj. njezinom načinu razmišljanja i pogledu na svijet. Isto mišljenje dijeli i Užarević (2012) koji spominje svekontekstualnost poslovica tj. beskontekstualnost. Bagić (2012) ističe da poslovicu ne treba miješati s autorovom mudrom izrekom tj. sentencijom koja je nastala iz autorovih osobnih stavova prema životu. Visinko (2018) dijeli isto mišljenje te upućuje na važnost razlikovanja poslovica, aforizama i frazema. Poslovice i frazemi povezani su tako, da su neke poslovice nastale na temelju frazema, a neki frazemi na temelju poslovica.

Kad je riječ o teorijskom razvrstavanju poslovica Škreb-Stamać (1998) i Visinko (2018) razvrstavaju poslovice prema semantičkom području na povijesne poslovice, etnološke, filozofske, političke, sociološke, društvene, kalendarske, moralne, profesijske, psihološke i vjerske. Škreb-Stamać (1998) zaključuju da poslovice ne treba razvrstavati po njihovoj tematici jer svaki pojedinac drugačije

1 Termin poslovica (Bagić, 2012) prvi je upotrijebio J. Stulli (1806), a sve do 19. st. poslovice su se s latinskog proverbium prevodile na hrvatski jezik kao priričje, proričje, priričak i sl. Kekez (1996) navodi da se zbog velikog interesa u svjetskoj književnosti za poslovice, razvija znanstvena disciplina koja se bavi poslovicama, a naziva se paremilogija. 
gleda na životne pojavnosti koje se u njima izdvajaju, a one se poistovjećuju s društvenim iskustvom. Kekez (1996) navodi da raznolikost paremioloških grupacija upućuje na njihovu podjelu prema kompoziciji (poslovice ili potpune poslovice, izreke, poslovice-pitalice, poslovice-anegdote ili poslovice pričice, paremiologizmi) Škreb i Stamić (1998) još izdvajaju šesti i sedmi paremiološki tip (šesti tip: kletve, zakletve, proklinjanja, sedmi blagoslovi). Prema Užareviću (2012) poslovice kao minimalni književni žanr sadrže: događaje, tempolarnost, semantičko-logičku povezanost što je neophodno da bi ih mogli smatrati protonarativima. Stoga poslovice kao protonarative možemo razvrstati i po sljedećim kriterijima: u prvu skupinu ulaze poslovice u kojima ima događaja, ali između tih događaja nema temporalnih veza. Glavno konstrukcijsko načelo kod ovih poslovica zasnovano je na povezanosti ili nepovezanosti suprotstavljenih događaja, na prostornim odnosima, količinskim, kvalitativnim ili na subjektnopredikatnim vezama (Krv nije voda). Poslovice u kojima među događajima nema temporalnih veza, već možemo uočiti samo logičke veze spadaju u drugu skupinu (Sve se može što se hoće). Trećoj skupini pripadaju poslovice gdje među događajima uočavamo semantičko-logičku povezanost i gdje se već mogu uočiti i temporalni odnosi (Gdje ima dima ima i vatre). U četvrtu skupinu ulaze poslovice kod kojih među događajima jasno uočavamo temporalne i semantičko-logičke veze. $\mathrm{U}$ ovim poslovicama je drugi događaj izrečen u poslovici, rezultat prvog događaja (Ispeci pa reci). U petu skupinu ulaze poslovice kod kojih se događaji odvijaju istovremeno dok se njihova smislena veza temelji na suprotstavljenim pojmovima (Hvali more, drž se kraja).

Solar (1984) uočava i poetsku strukturu poslovica jer su poslovice bogate izražajnim jezičnim elementima kao što su npr. ritam i rima. „Elegancija, diskurzivna gipkost i razgranato značenje poslovica zasniva se na njihovoj bogatoj figurativnosti“" (Bagić, 2012, 261). Suvremena stilistika poslovicu smješta u figuru diskurza. Prema Bagiću (2016) poslovice su najčešće bogate stilskim figurama: alegorijom, metaforom, poredbom, personifikacijom, a u nekim je poslovicama iskaz zasnovan na povezivanju dviju sintagmi suprotnog značenja. Užarević (2012) stavlja naglasak i na kompoziciju poslovica koja se sastoji od dva dijela, doslovni i preneseni, te na njihov smisao za ironiju i paradoks. Drugi, preneseni dio važan je za poslovice jer se njime na slikovit način može prikazati njihova umjetnička vrijednost. Također valja napomenuti da postoje i poslovice koje nemaju prenesenog, slikovitog djela, a ipak su univerzalne i višeznačne. Povezano s time u poslovicama susrećemo desematizaciju i resemantizaciju riječ. Desematizacija se odnosi na samu riječ koja je izgubila svoje prvotno leksičko značenje dok se resematizacija odnosi na čitavu poslovicu te ona ovisi o kontekstu u koji se svrstava. 
Kada je riječ o jezičnom obliku poslovica tj. rečeničnoj strukturu Visinko nalazi da „Među njima je najviše sastavljenih od dviju nezavisnih surečenica ili od glavne i zavisne surečenice, a najmanje je višestruko složenih rečenica. U morfološkim je opisima poslovičnih rečenica i glagolskih i imenskih predikata, od glagolskih oblika za izricanje sadašnjeg, prošlog i budućeg vremena najčešći su prezent i perfekt, rjeđe se pojavljuju aorist, imperfekt, pluskvamperfekt i futur prvi i futur drugi, a od glagolskih je načina najčešći izjavni, potom imperativ za izricanje opomene, zabrane, zahtjeva, ili savjeta, dok se rjeđe bilježe poslovice u optativu i kondicionalu." $(2018,12)$.

Stoga poslovice osim u književnim djelima ${ }^{2}$ možemo susresti u svim medijskim iskazima i oblicima kao i u svakodnevnoj komunikaciji.

\section{METODIČKI PRISTUP POSLOVICAMA}

Suvremene metodike ne bave se poslovicama, već ih kratko spominju. Kod Rosandića (1986) poslovice sejavljaju u poglavljuo narodnojknjiževnosti. Navedenim oblicima učenika se potičena razvijanje mašte, mišljena te na sposobnostzaključivanja i izražavanja. Musa, Šušić, Tokić spominju poslovice kao dio „kratke pripovjedne proze u nastavi književnosti“ $(2015,166)$. Također izdvajaju njihovu primjenu u nastavi kroz motivaciju i jezične igre. Najznačajniji doprinos poslovicama u nastavi donijela je monografija Karol Visinko (2018) Zvona zvone jer su potezna: primjena poslovica u nastavi hrvatskoga jezika, jezičnog izražavanja i književnosti. Visinko (2018) naglašava čestu upotrebu poslovica u raznim nastavnim situacijama i njihovo pojavljivanje u školskoj praksi. Istraživanja koja su provedena među učenicima 4. razreda i studentima potvrđuju zapamćivanje onih poslovica koje su se spominjale i objašnjavale na nastavi hrvatskog jezika. Visinko objašnjava da nam poslovica u odgojno-obrazovnom procesu može poslužiti kao „pomoćnica (Poslovica-svakom poslu pomoćnica); dobar začin sadržaju (Riječ bez poslovice kao jelo bez soli); učinkovit način poučavanja (Riječi su djedov izvor mudrosti.) i očuvanja bliskosti s tradicijom kojoj pripada (Tradiciju ne nastavljaju mrtvi spomenici, nego živi ljudi.); počesto u poveznici $s$ razumijevanjem doticaja s ostalim narodima, zemljama $\mathrm{i}$ jezicima (Sua servat, qui salva esse vult communia. / Svoje čuva tko nastoji da bude sačuvano zajedničko.)“( $(2018,26)$. Također spominje poslovice u funkciji početnog čitanja, odnosno njihovu primjenu u globalnom čitanju.

U prvoj polovici 20. stoljeća prepoznata je odgojna i obrazovna funkcija poslovica u nastavi. Svjedoči o tome knjižica iz 1906. tiskana u Dubrovniku s

2 Poslovice nalazimo i u suvremenoj dječjoj književnosti, i to u slikovnicama. Ističemo osmišljenu uklopljenost u slikovnici Cic i Mic autorice Manuele Vladić Maštruko. 
naslovom Razni didaktički postupci za tumačenje poslovica i zagonetki autorice NikeBalerin ${ }^{3}$. Riječje o priručniku strukturiranom od teorijskog dijela, metodičkog pristupa poslovicama i metodičkih modela nastave poslovica. Već na početku saznajemo da su poslovice uključene u nastavni program, red obuke. Priručnik počinje objašnjenjem da su poslovice „produkti naroda izvađeni iz praktičnog životnoga iskustva pojedinca i svijeh“(Balerin, 1906, 3). Ističe se raznolikost oblika i tema poslovica. Smisao poslovice nije uvredljivost već su one „u najdubljem temelju što drugo no propovijednice ćudorednosti“ (Balerin, 1906, 4). Autorica ističe da ih nalazimo u čitankama i da se mogu rabiti u svim stupnjevima nastave te predlaže ovakav raspored: u prvom razredu treba pričati priču iz koje proizlazi poslovica, a u drugom i trećem razredu „osim što djeci pripovjedi pripovijest iz koje izlazi smisao poslovice, to mora još da nastoji, da djeca shvate pravi i preneseni smisao i da nauče, kada se upotrebljava“"(Balerin, 1906, 5). Predlaže put dedukcije i četiri nastave etape (četiri stupnja): tumačenje nepoznatih riječi, protumačiti smisao poslovice, dokazati istinitost ili neistinitost poslovice, uporaba ili sastav. Navodi metodički model obrade poslovice Dobro se djelo isplati. Autorica ističe da se poslovica može primijeniti u nastavi drugih sadržaja primjerice za slovničko vježbanje i u nastavi drugih područja kao nastavi povijesti, katekizma. Zaključuje da iz svega "proizlazi kakvo blago imamo u našim narodnim poslovicama i kako se one mogu upotrebljavati ne samo kao praktični kažiput u životu, nego kao i korisni materijal u školskoj pouci“ (Balerin, 1906, 11).

Nastavni plan i program (2006) u primarnom obrazovanju ne spominje poslovice. Prema HNOS-u poslovica se kao književni termin spominje prvi put $\mathrm{u}$ predmetnoj nastavi u petom razredu u nastavnom području Književnost pod temom preneseno značenje u književnom djelu. Prema novom predmetnom kurikulumu (2019) nastavni predmet Hrvatski jezik strukturiran je kroz tri područja: Hrvatski jezik i komunikacija, Književnost i stvaralaštvo, Kultura i mediji, za svako područje ima navedene odgojno-obrazovne ishode, njihovu razradu, razinu usvojenosti na kraju svakog razreda te navedene sadržaje na temelju kojih će se odgojno-obrazovni ishodi ostvariti. U četvrtom razredu pojavljuje se poslovica po prvi put kao književni termin zajedno s drugim književnim tekstovima koji su navedeni kao sadržaji za ostvarenje odgojnoobrazovnih ishoda, a to su priča, pripovijetka, pjesma, igrokaz i dječji roman. Učenik osim što razlikuje i povezuje također i objašnjava osnovna obilježja poslovice i drugih tekstova.

3 Učiteljica (1875-1925, Dubrovnik) kao upraviteljica Ženske osnovne škole i odbornica Narodne ženske zadruge aktivno je sudjelovala u kulturnom i prosvjetnom životu Dubrovnika. Skupila je vrijednu zbirku konavoskih ženskih ručnih radova i zabilježila svadbene običaje i tradicijska vjerovanja Konavala (Gruda). 
Poslovice imaju dugu povijest u učenju i nastavi koja je vidljiva upravo kroz pisane izvore. Nalazimo ih u gramatikama 18. i 19. stoljeća koje su kontrastivne i služile su za opismenjavanje te učenju hrvatskog i nekog drugog jezika, odnosno jezika službene i javne komunikacije i bile prisutne u obrazovanju. U njemačkohrvatskoj gramatici Blaža Tadijanovića Shvaschta po malo iz 1761. godine pod naslovom Prigvorenye Kojefe med Lyudma ù Razgovoru obicfaje dogoditti nalazimo dvadeset poslovica koje su i danas u uporabi kao npr. Tko zna govoriti, mlogo zna; alli koji zna Schutiti vechje zna. Savjetuje autor da ih je dobro upotrebljavati u razgovoru. Franjo Marija Appendini u gramatici talijanskog jezika pisanoj hrvatskim jezikom Grammatica della lingua illirica iz 1808. godine donosi 117 poslovica kao npr. Pusto mljeko i psi loccju. Star vuk pasija maskara. Šime Starčević u prvoj nekontrastivnoj gramatici hrvatskog jezika Nova ricsoslovica iliricska iz 1812. godine u dijelu koji je namijenjen učenju čitanja i

pisanja navodi 75 polovica kao npr. Pusto mliko i psi locsu. Ruka ruku umiva, a obraz obedvi. Razvidna je namjera Starčevića da se u učenju i vježbanju čitanja polazi od poznatog ka nepoznatom. Nije rijedak postupak da se javljaju poslovice u gramatičkim primjerima.

\section{POSLOVICE U UDŽBENICIMA}

Temeljni izvor znanja u odgoju i obrazovanju učenika uz učitelja je upravo udžbenik/čitanka. U razrednoj nastavi udžbenik/čitanka se smatra svojevrsnom dječjom knjigom koja je sadržajno, strukturalno i estetski prilagođena recepcijskim sposobnostima učenika (Rosandić, 2005).

Zapravo su poslovice prisutne u udžbenicima već godinama. Nalazimo poslovice u udžbenicima iz 19. stoljeća. Navodimo samo primjere iz početnica koji pokazuju da se poslovice javljaju već na početku školske prakse: Ne valja Zlo sa Zlim vratjati. (ABC iliti knjixica slovoznanja, za potribu narodnih ucsionicah u kraljestvu Slavonie, 1823), Krivo stečeno nije blagoslovljeno. (Abecedar za děcu, 1847), Teško nogama pod ludom glavom. (Početnica za obće pučke škole, 1877). Također i u početnicama iz 20 stoljeća: Čuvaj bijele novce za crne dane. Fina roba lako kupca nađe. Više vrijedi poštenje negolo suho zlato. (Početnica za I razred osnovne škole, 1933); Tko uči taj zna. U mladosti tko ne uči, kasnije se mnogo muči! (Početnica i čitanka, 1948.); Gvožđe se kuje dok je vruće. (Početnica, 1954). Razvidno je da tek novi kurikul smješta poslovice kao književni oblik u primarno obrazovanje, ali iz gore navedenog razvidno je da su prisutne $u$ poučavanju i $u$ udžbenicima. Jesu li poslovice prisutne u suvremenim udžbenicima koji se danas primjenjuju? 
$\mathrm{Na}$ temelju dostupnosti udžbenika uzorak analize činili su slučajno odabrani udžbenici za prvi, drugi, treći i četvrti razred osnovne škole. Za prva tri razreda u analizi su korišteni udžbenici prema kurikulu iz 2019. godine, odobreni od Ministarstva znanosti i obrazovanja za školsku godinu 2020./2021. S obzirom na to da kurikularna reforma tek od školske godine 2021./2022. ulazi u četvrte razrede osnovne škole pri analizi udžbenika za četvrti razred iz hrvatskog jezika korišten je udžbenik iz 2015., prema HNOS-u, također odobren od resornog ministarstva. U Tablici 1. prikazana je pojavnost poslovica.

Tablica 1. Poslovice u udžbenicima

\begin{tabular}{ccccc}
\hline & Udžbenik 1 & Udžbenik 2 & Udžbenik 3 & Udžbenik 4 \\
\hline Poslovice & 4 & 2 & 0 & 5 \\
\hline
\end{tabular}

U udžbeniku za prvi razred javljaju se ove poslovice:

Zrno do zrno pogača, kamen do kamena plača.

Žuti žutuju, a crveni putuju.

Dobro se dobrim vraća.

Dobrota je najveće blago.

Jedna poslovica javlja se uklopljena u književni tekst (izgovara je lik), ostale se javljaju u metodičkom instrumentariju za stvaralačke zadatke (Razmisli i stvaraj) i to vezano uz lirsku pjesmu i animirani film.

U udžbeniku za drugi razred javljaju se ove dvije poslovice:

Jedna jabuka na dan, tjera doktora iz kuće van.

Oko za oko, zub za zub.

I ove poslovice javljaju se u metodičkom instrumentariju koji učenike potiče na stvaralački, kreativan i istraživački rad (Možeš i ovo). Obadvije su vezane uz teme proznih književnih tekstova.

U analiziranom udžbeniku za treći razred nije nađena poslovica, a ove se nalaze u udžbeniku za četvrti razred:

Svuda je lijepo, ali kod kuće je najljepše.

Za svadu je potrebno dvoje.

Što si posijao, to i žanji.

Vuk dlaku mijenja, ali ćud nikada.

Zabranjeno voće je najslađe. 
Jedna poslovica je uklopljena u književni tekst (basna), jedna je u metodičkom instrumentariju za primanje teksta, motivaciju, a ostale tri su dio metodičkog instrumentarija za stvaralački rad vezano uz književni tekst (Izražavam se i stvaram).

U ovom pilot istraživanju na slučajno odabranim udžbenicima željelo se potvrditi kontinuitet prisustva poslovica u udžbenicima, a to znači i u nastavi, nezavisno od nastavnih programa. Razvidno je da se poslovice najviše javljaju u metodičkim sredstvima koja potiču i razvijaju različite oblike samostalnog i stvaralačkog rada učenika, a sporadično se javljaju u motivacijskom dijelu sata. Poslovice uglavnom tematiziraju književni tekst uz koji se nalaze i od učenika se traži da ih objasni, prepoznavajući tako povezanost s tekstom. Također se javljaju kao poticaj stvaralačkom pisanju. Upoznavanje poslovice kao književne vrste nije zastupljeno, kao ni uvođenje učenika u značajke poslovice i recepciju poslovice s obzirom na zgusnuti tekst i preneseno značenje. To je prepušteno učeniku i učitelju.

\section{ISTRAŽIVANJE UČENIČKE RECEPGIJE POSLOVICA}

Prilikom određivanja sadržaja nastavnih programa, metodičkih priručnika i udžbeničkih kompleta važno je uzeti u obzir psihološki, spoznajni razvoj učenika. Za metodiku nastave Hrvatskog jezika važna su dva razdoblja, a to su razdoblje konkretnih operacija koje se odnosi na niže razrede osnovne škole i razdoblje formalnih operacija koje je važno za predmetnu nastavu. Istraživanjem učeničke percepcije poslovica dobiva se uvid koliko učenici nižih razreda razumiju ove književne oblike.

\section{METODOLOGIJA ISTRAŽIVANJA}

\section{Cilj istraživanja}

Cilj ovog istraživanja je analizirati koliko učenici trećih i četvrtih razreda razumiju poslovice. Također se želi ustanoviti je li uvođenje ove književne vrste u niže razrede osnovne škole, u razdoblje konkretnih operacija, opravdano.

\section{Hipoteze}

1. Učenici trećih i četvrtih razreda imaju poteškoće u razumijevanju poslovica.

2. Učenici trećih i četvrtih razreda pokazuju sposobnosti za postupno upoznavanje značenja pojedinih poslovica.

3. Učenici ne mogu samostalno objasniti značenje poslovica.

4. Dob učenika ovisi o razumijevanju poslovica. 


\section{Uzorak}

U istraživanju su sudjelovali učenici trećih i četvrtih razreda iz Osnovne škole Banija u Karlovcu. U oba treća i četvrta razreda ima osamdeset i dva učenika, a istraživanju je pristupilo njih šezdeset i dvoje. U trećim razredima ispitana su dvadeset i četiri učenika, osam djevojčica i šesnaest dječaka, a u oba četvrta razreda ispitano je trideset i osam učenika, dvadeset i četiri djevojčice i četrnaest dječaka. Prosječna dob učenik trećih razreda je između devet i deset godina, a ispitanika četvrtih razreda između deset i jedanaest godina. Položaj svih ispitanika u razrednim odjelima je sličan.

\section{Instrument mjerenja}

U svrhu ovog istraživanja korišten je oblikovni anketni upitnik. Anketa se sastoji od tri tipa zadatka: zadatak zatvorenog tipa, zadatak povezivanja i zadatak otvorenog tipa, a sadrži šest slučajno odabranih poslovica koje se pojavljuju u udžbenicima iz Hrvatskog jezika od prvog do četvrtog razreda. Pitanja su bila oblikovana u svrhu provjere razumijevanja poslovica te su također bila prilagođena spoznajnim mogućnostima učenika.

\section{Postupak}

Istraživanje je provedeno u lipnju, krajem školske godine 2019./2020. na nastavnom satu prema Etičkom kodeksu istraživanja djece (2003) uz dopuštenje roditelja i škole. Učenicima je na početku sata podijeljena anketa te im je objašnjeno što se od njih očekuje.

\section{REZULTATI ISTRAŽIVANJA}

Rezultati istraživanja za svaki razred i svaki zadatak prikazani su grafički. Prikaz odgovora na prvi zadatak:

1. Za navedene rečenice odaberi (zaokruži) odgovarajuću poslovicu.

a. Pravilnom i uravnoteženom prehranom brinemo o zdravlju.

a) Što si posijao to $i \check{z} a n j i$.

b) Jedna jabuka na dan tjera doktora iz kuće van.

c) Zabranjeno voće je najslađe. 
b. Čovjek mijenja svoje loše ponašanje samo kada je njemu to potrebno.

a) Za svadu je potrebno dvoje.

b) Dobrota je najveće blago.

c) Vuk dlaku mijenja, ali ćud nikada.

Grafikon 1. Prikaz odgovora ispitanika

\section{Prvo pitanje - A Prvo pitanje - B}

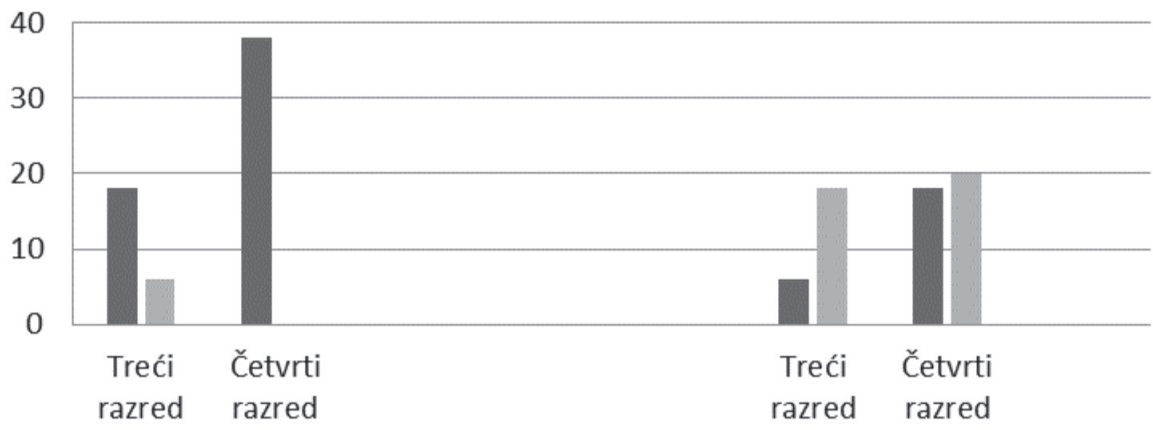

- Točno Netočno

„A“ zadatkom željelo se utvrditi razumiju li učenici poslovice u kojima su odnosi među događajima zasnovani na logičkoj povezanosti. Obradom rezultata u trećem razredu točno je odgovorilo 18 (75\%) učenika te su kao točan odgovor zaokružili poslovicu Jedna jabuka na dan tjera doktora iz kuće van. Netočno je odgovorilo 6 (25\%) učenika zaokruživši poslovice Što si posijao to i žanji (3) i Zabranjeno voće je najslađe (3). Učenici četvrtih razreda pokazuju bolju razvijenost logičkog mišljenja te pri rješavanju ovog zadatka nisu imali poteškoća, stoga je 38 (100\%) učenika odgovorilo točno. Na temelju obrađenih rezultata ovim zadatkom poništena je prva hipoteza te se ustanovilo da učenici razumiju poslovice kod kojih su odnosi među događajima zasnovani na logičkoj povezanosti.

„B“ zadatkom željelo se ustanoviti imaju li učenici poteškoća s poslovicama koje zahtijevaju razumijevanje prenesenog značenja suprotstavljenih događaja. U trećem razredu na postavljeno pitanje točno je odgovorilo 6 (25\%) učenika koji su se opredijelili za odgovor Vuk dlaku mijenja, ali ćud nikada. Netočno je odgovorilo 18 (75\%) učenika zaokruživši poslovice: Za svađu je potrebno dvoje (6) i Dobrota je najveće blago (12). U četvrtom razredu 18 (47\%) učenika je odgovorilo točno, a 20 (53\%) netočno zaokruživši poslovice: Za svađu je potrebno dvoje (4) i Dobrota 
je najveće blago (16). Analizom 1.B zadatka vidljivo je da učenici imaju poteškoće s poslovicama koje zahtijevaju potpuno razumijevanje prenesenog značenja, a time je potvrđena prva hipoteza. Učenici četvrtih razreda postigli su bolje rezultate od učenika trećih razreda te je ovima potvrđena četvrta hipoteza kojom je iskazano da dob učenika utječe na razumijevanje poslovica.

Prikaz odgovora na drugi zadatak:

2. Navedene poslovice spoji sodgovarajućim značenjem poslovice.

a) Zrno do zrno pogača, kamen do kamena palača.

b) Svuda je lijepo, ali je kod kuće najliepše.

c) Oko za oko, zub za zub.

d) Pravda ne treba uvijek biti zadovoljena na način na koji se desila nepravda.

e) Gdje god otišli, domu i obitelji ćemo se uvijek vratiti.

f) U životu treba štedjeti kako bismo si mogli priuštiti ono što želimo.

Grafikon 2. Prikaz odgovora ispitanika

\section{Drugo pitanje}

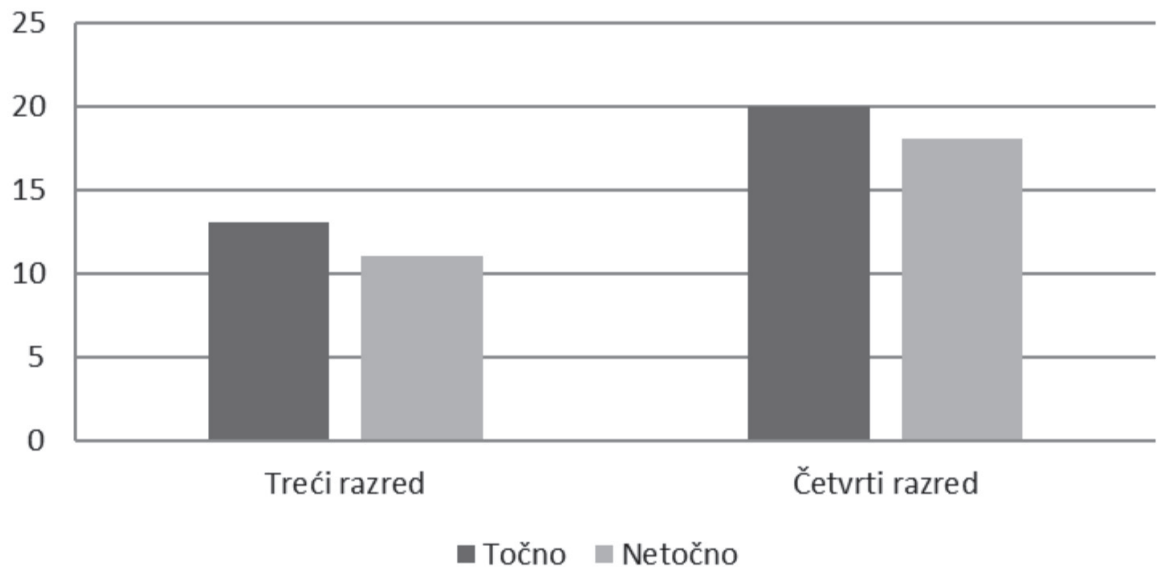

Drugim pitanjem željelo se ustanoviti imaju li učenici trećih i četvrtih razreda razvijene sposobnosti za postupno upoznavanje značenja pojedinih poslovica. $\mathrm{Na}$ drugo pitanje u trećem razredu točno je odgovorilo 13 (54\%) učenika, povezavši poslovice s odgovarajućim objašnjenjem kao što je prikazano u Slici 1. Ostatak učenika, odnosno njih 11 (46\%) odgovorilo je netočno. 
Slika 1. Primjer točnog odgovora

2. Navedene poslovice spoji s odgovarajućim značenjem poslovice.
a) Zrno do zrno pogača, kamen do kamena
d) Pravda ne treba uvijek biti zadovoljena na plača.
b) Svuda je lijepo, ali je kod kuće je najljepše. način na koji se desila nepravda.
c) Oko za oko, zub za zub.
e) Gdje god otisli, domu i obitelji ćemo se uvijek vratiti.
f) U životu treba štedjeti kako bismo si mogli priuštiti ono što želimo.

U četvrtom razredu na drugo pitanje točno je odgovorilo 20 (53\%) učenika, a netočno 18 (47\%) učenika. Ovim odgovorima potvrđena je druga hipoteza.

Prikaz odgovora na treći zadatak:

3. Objasni značenje poslovice: Dobro se dobrim vraća.

Grafikon 3. Prikaz odgovora ispitanika

\section{Treće pitanje}

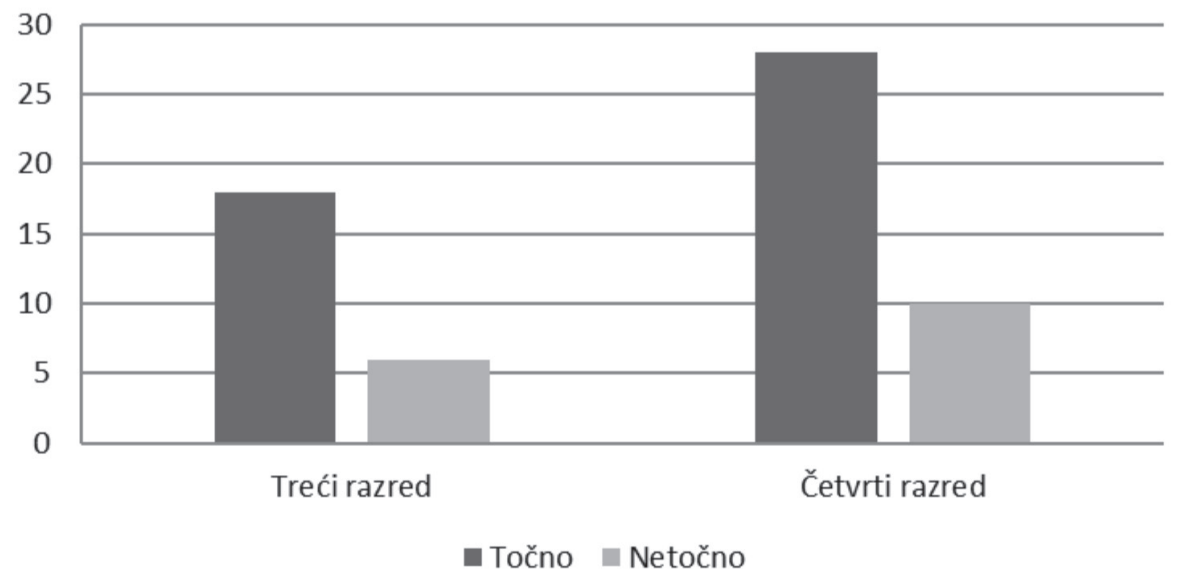

Trećim pitanjem željelo su utvrditi mogu li učenici samostalno objasniti poslovicu u kojoj su odnosi među događajima logički povezani. Na treće pitanje u trećem razredu točno je odgovorilo 18 (75\%) učenika. Neki od odgovora glase: Ako si prema nekome dobar i on će takav biti prema tebi; Ako nekom pomogneš 
vratit će ti se; Ako napraviš nešto dobro to će ti se vratiti. Netočno je odgovorilo 6 (25\%) učenika dajući odgovore poput ovih: To znači ako prijatelju nisi htio posuditi olovku neće ni on tebi; Dobro će uvijek živjeti; Kad odeš ono će se vratiti kad tad. U četvrtom razredu točno je odgovorilo 28 (74\%) učenika, a neki od odgovora glase: Ako si dobar prema drugima i drugi će biti dobri prema tebi; Ako napraviš nešto dobro taj će ti čovjek vratiti dobro; To znači da ako si ti ljubazan i dobar prema drugima da će najčešće i oni biti takvi prema tebi. Netočne je odgovorilo 10 (26\%) učenika dajući neke od ovih odgovora: Onaj koji je dobar dobro će živjeti; Ja bi ovo opisala tako što ako je netko dobar nešto će se lijepo desiti; Kad je dobar i kad pomaže. Obradom rezultata trećeg zadatka nije potvrđena treća hipoteza te se ustanovilo da većina učenika može bez poteškoća objasniti poslovice kod kojih su odnosi među događajima zasnovani na logičkoj povezanosti.

Provedenom analizom utvrđeno je da učenici trećihi četvrtih razreda pokazuju razumijevanje poslovica kod kojih su odnosi među događajima zasnovani na logičkoj povezanosti. Na temelju ovih rezultata vidljivo je postepeno ovladavanje logičkim mišljenjem. Slabije rezultate učenici su postigli u zadatku koji od učenika zahtijeva poznavanje prenesenog značenja. $\mathrm{Na}$ temelju navedenih rezultata zaključuje se da učenici četvrtih razreda pokazuju veću razvijenost recepcijskih sposobnosti za preneseno značenje od učenika trećih razreda. Također je važno naglasiti kako razvijenost apstraktnog mišljenja nije svojstvena za učenike trećeg $\mathrm{i}$ četvrtog razreda te da su postignuti rezultati iz tog razloga zadovoljavajući. Drugim zadatkom se željela skrenuti pozornost na to koliko učenici uopće razumiju poslovice koje zahtijevaju razvijenost logičkih i apstraktnih mentalnih operacija. Rezultati pokazuju spremnost učenika za postepenu komunikaciju s pojedinim poslovicama. Ovim upitnikom se željelo utvrditi jesu li učenici kompetentni za samostalno objašnjavanje poslovice koja zahtijeva usvojenost logičkog mišljenja te je u zadnjem zadatku $75 \%$ učenika trećih i $74 \%$ učenika četvrtih razreda uspješno objasnilo značenje poslovice. Na temelju provedenog istraživanja može se zaključiti da su misaoni procesi učenika u razdoblju konkretnih operacija spremni za postepeno upoznavanje značenja poslovice. Pojedini učenici trećih i četvrtih razreda već u ovom razvojnom razdoblju pokazuju razumijevanje prenesenih pojmova i događaja dok se većina učenika bolje „snalazi“ s poslovicama koje su utemeljene na stvarnim, konkretnim i logičkim događajima.

Možemo zaključiti da učenici trećih i četvrtih razreda u ovom odgojnoobrazovnom razdoblju pokazuju relativno dobro razumijevanje poslovica koje se pojavljuju u udžbenicima. Važno je naglasiti da percepcija poslovica kod učenika ponekad ne ovisi o dobi učenika već o pojedincu. Oni pojedinci koji su ovladali svim sposobnostima iz razdoblja konkretnih operacija pokazuju veću razvijenost 
i osjećaj za logičko i preneseno rasuđivanje koje je svojstveno razdoblju formalnih operacija. Uključivanje poslovice u nastavu u nižim razredima osnovne škole je itekako opravdano jer osim što potiče učenika na razmišljanje i izražavanje ima i odgojnu ulogu.

\section{ZAKLJUČAK}

Iako novi kurikul Hrvatskog jezika uvodi poslovice u nastavu kao književni tekst one su većstoljećima prisutne unastavi. Poslovice kao maleformekarakterizira zgusnuti tekst, preneseno značenje koje zahtijeva složene operacije primjerenije predmetnoj nastavi Hrvatskog jezika nego nastavi u nižim razredima osnovne škole. Nalazimo poslovice u povijesnim početcima obrazovanja i u prvim udžbenicima. Kako ti udžbenici nemaju ili imaju skroman metodički instrumentarij, poslovice svjedoče da su autori uključivali u udžbenike ono što okružuje učenike i što im je najvjerojatnije bilo poznato. Analiza odabranih suvremenih udžbenika za mlađe osnovce pokazala je tradiciju prisutnosti poslovica u njima. Nažalost, one su najčešće popratni dio književnog teksta i učenik nije vođen u recepciji poslovica. Jasno je da je uloga učitelja najvažnija u otkrivanju značenja ili mogućih recepcijskih zapreka. Istraživanje $u$ trećim i četvrtim razredima učeničke komunikacije i recepcije poslovica pokazalo je učeničku spremnost za samostalni susret s poslovicama. Istraživanjem je potvrđeno da učenici pokazuju veće razumijevanje poslovica kod kojih su odnosi među događajima zasnovani na logičkoj povezanosti, dok s poslovicama koje zahtijevaju razumijevanje prenesenog značenja imaju poteškoća. Učenici četvrtih razreda pokazuju bolje razumijevanje poslovica koje zahtijevaju ovladavanje prenesenim značenjem. Ipak, s obzirom na dob učenika, književnoteorijsko i čitateljsko iskustvo moguće su recepcijske zapreke. One su moguće upravo u preoblikovanju značenja, u dekodiranju poruke i smisla. Razvidna je metodička opravdanost uvođenja poslovica u kurikul za niže razrede osnovne škole te postepeno uvođenje učenika u komunikaciju s poslovicama. Svakako bi poslovice trebale biti sadržaj, a ne samo dio metodičkog instrumentarija uz druge književne tekstove. 


\section{LITERATURA}

1. Bagić, K. (2012). Rječnik stilskih figura. Zagreb: Školska knjiga.

2. Balarin-Monopoli, N. (1906). Razni didaktički postupci za tumačenje poslovica i zagonetka. Dubrovnik: Štamparija Degiulli i dr.

3. Etički kodeks istraživanja s djecom. (2003). U: M. Ajduković;V. Kolesaroć (ur.). Zagreb: Državni zavod za zaštitu materinstva i mladeži, Vijeće za djecu Vlade Republike Hrvatske.

4. Jolles, A. (2000). Jednostavni oblici. Zagreb: Matica hrvatska.

5. Kekez, J. (1996). Poslovice, zagonetke i govornički oblici. Zagreb: Matica hrvatska.

6. Kurikulum nastavnog predmeta Hrvatski jezik za osnovne škole i gimnazije. (2019). Zagreb: Ministarstvo znanosti i obrazovanja. s mreže preuzeto 30. listopada 2020. sa https://narodnenovine.nn.hr/clanci/sluzbeni/2019_01_10_215.html

7. Musa, Š., Šušić, M., Tokić, M. (2015). Uvod u metodiku, interpretaciju i recepciju književnosti. Zadar: Sveučilište u Zadru.

8. Nastavni plan i program za osnovnu školu. (2006). Zagreb: Ministarstvo znanosti obrazovanja i športa.

9. Rosandić, D. (1986). Metodika književnog odgoja i obrazovanja. Zagreb: Školska knjiga.

10. Rosandić, D. (2005). Metodika književnog odgoja. Zagreb: Školska knjiga.

11. Solar, M., (1984). Teorija književnosti. Zagreb: Školska knjiga.

12. Škreb, Z., Stamać, A. (1998). Uvod u književnost: teorija, metodologija. Zagreb: Nakladni Zavod Globus.

13. Užarević, J. (2012). Književni minimalizam. Zagreb: Disput.

14. Visinko, K., (2018). Zvona zvone jer su potezna: primjena poslovica u nastavi hrvatskoga jezika, jezičnog izražavanja i književnosti. Zagreb: Profil Klett.

\section{IZVORI}

1. ABC iliti knjixica slovoznanja za potribu narodnih ucsionicah u kraljestvu Slavonie. (1823). Pešta.

2. Antoliću, I. (1847). Abecedar za děcu. Karlovac.

3. Appendini, F. M. (1808). Grammatica della lingua Illirica. Dubrovnik.

4. Modec, Lj. (1877). Početnica za obće pučke škole. Zagreb.

5. Tošić, I., Cvitan, V. (1948). Početnica i čitanka za I. razred osnovne škole. Zagreb : Nakladni zavod Hrvatske.

6. Početnica za I. razred narodne škole. (1954). Zagreb: Školska knjiga.

7. Pavličević-Franić, D., Velički, V., Aladrović Slovaček, K., Domišljanović, V. (2020). Čitam i pišem 1, hrvatska početnica, hrvatska čitančica. Zagreb:Alfa.

8. Pavličević-Franić, D., Velički, V., Aladrović Slovaček, K., Domišljanović, V. (2020). Čitam i pišem 2. Zagreb: Alfa. 
9. Pavličević-Franić, D., Velički, V., Aladrović Slovaček, K., Domišljanović, V. (2020). Čitam i pišem 3. Zagreb:Alfa.

10. Starčević, Š. (1812). Nova ricsoslovica iliricsko - francezka. Trst.

11. Špoljar, Z. (1933). Početnica za I razred osnovnih škola u Kraljevini Jugoslaviji. Zagreb: Tipografija.

12. Tadijanović, B. (1761). Shvaschta po malo, iliti kratko sloxenye immenah, i ricsih u iliyrski, i nyemacski jezik. Magdeburg.

13. Težak, D., Polak, S., Cindrić. (2015). Čarolija riječi, čitanaka i jezični udžbenik za četvrti razred osnovne škole. Zagreb: Alfa.

14. Turza-Bogdan, T., Pospiš, S., Velički, V. (2020). Čitam i pišem 2, Čitanka. Zagreb: Alfa.

15. Turza-Bogdan, T., Pospiš, S., Velički, V. (2020). Čitam i pišem 3, Čitanka. Zagreb: Alfa. 


\section{PROVERBS IN ELEMENTARY SGHOOL}

\section{ABSTRACT}

The new 2019 curriculum for lower grades of Croatian primary schools introduces proverbs among the recommended literary texts for teaching. This work begins with the theoretical definition of proverbs and determines their presence in learning and teaching in past times. This shows the justification of the presence of proverbs in teaching today. The analysis of the textbook on the selected sample gives an overview of the position of proverbs in teaching that appear as accompanying methodological material for literary and linguistic contents of teaching. The research conducted within this paper was on students' communication with proverbs as a condensed and concise form, and the existence of reception barriers was established.

Keywords: proverb, teaching, textbook, student, teacher. 